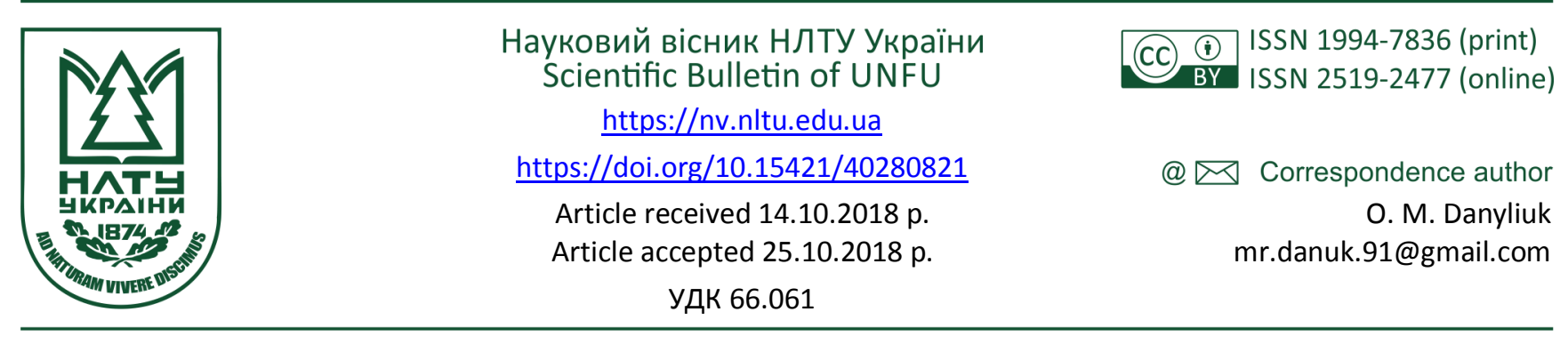

О. М. Данилюк, В. М. Атаманюк, З. Я. Гнатів, Я. М. Гумницький

Національний університет "Львівська політехніка", м. Львів, Україна

\title{
ДОСЛІДЖЕННЯ МАСООБМІНУ ПІД ЧАС ПНЕВМАТИЧНОГО РОЗЧИНЕННЯ ПОЛІДИСПЕРСНОЇ СУМІШІ БЕНЗОЙНОЇ КИСЛОТИ
}

Наведено результати експериментальних досліджень розчинення бензойної кислоти під час пневматичного перемішування. Проаналізовано літературні джерела і показано актуальність дослідження закономірностей масообмінних процесів під час розчинення полідисперсних сумішей. Обгрунтовано припущення щодо зміни діаметрів твердих частинок під час розчинення. Отримано залежності зміни діаметра полідисперсних частинок бензойної кислоти від зміни концентрації розчину за сталої та змінної витрат стисненого повітря для полідисперсної суміші бензойної кислоти та окремо для кожної із фракцій. Наведено обчислені та експериментальні результати, згідно з якими площа поверхні масообміну полідисперсної суміші бензойної кислоти зменшується в часі зі зростанням концентрації розчину. Отримано залежність коефіцієнта масовіддачі від зміни дисипації енергії в об'ємі апарату під час розчинення бензойної кислоти. Проаналізовано вплив зміни витрати стиснутого повітря на коефіцієнт масовіддачі. Зроблено узагальнення результатів експериментального визначення коефіцієнта масовіддачі бензойної кислоти під час пневматичного перемішування. Визначено коефіцієнт молекулярної дифузії за цієї температури, а також порівняно експериментальні дані з теоретично розрахованими. Отримано розрахункову залежність для розрахунку значень чисел Шервуда, а також порівняно їх із даними експериментальних досліджень. Оцінено похибку проведених розрахунків.

Ключові слова: бензойна кислота; полідисперсна суміш; розчинення; коефіцієнт масовіддачі; пневматичне перемішування; дифузія.

Вступ. Бензойна кислота $\left(\mathrm{C}_{6} \mathrm{H}_{5} \mathrm{COOH}\right)$, яку широко використовують у різних галузях хімічної, фармацевтичної, косметичної та харчової промисловості, у медицині, як консервант у деревообробній промисловості та ін., - це тверді кристали полідисперсного гранулометричного складу. Вона $є$ сировиною для виробництва багатьох продуктів, зокрема: капролактаму, віскози, барвників (анілінового синього, антрахінонових барвників), у медицині як протимікробний та фунгіцидний агент, а іiї солі - бензоати натрію, калію та кальцію використовують як консервант у харчовій промисловості (Thati, Nordström \& Rasmuson, 2010; Eryh \& Martyn, 1998; Osokina \& Gerasymchuk, 2008; Symak, Atamaniuk \& Gumnitsky, 2015; Melihov et al., 1989).

Огляд літературних джерел. Для використання бензойної кислоти у технологічних процесах іiі розчиняють у апаратах періодичної та безперервної дії. Процес розчинення бензойної кислоти відбувається переважно в дифузійній області. У роботі (Symak, Atamaniuk \& Gumnitsky, 2015) розглянуто процес розчинення полідисперсної суміші частинок бензойної кислоти в газорідинно-

му потоці. Експериментально та теоретично на підстаі критеріальної залежності та теорії локальної ізотропної турбулентності визначено коефіцієнт масовіддачі та порівняно їх значення. Також показано можливість застосування цього методу для теоретичного визначення коефіцієнта масовіддачі. Дослідженню розчинення одинарних частинок та розчинення у стаціонарному шарі приділили чимало уваги різні дослідники, зокрема у роботі (Melihov et al., 1989). У працях Гарнера та Гофмана наведено результати щодо визначення коефіцієнтів масовіддачі під час розчинення одинарних частинок бензойної кислоти кулястої форми внаслідок механічного перемішування (Garner \& Hoffman, 1960). У роботі (Harlashin, Beket \& Bendich, 2012) наведено кінетичні закономірності розчинення твердих розплавів і запропоновано рівняння для визначення коефіцієнта масопередачі. Зазвичай процес розчинення розглядають у двох аспектах: вивчення розчинності та кінетики процесу, а також аналіз методів інтенсифікації.

Розчинність бензойної кислоти у воді добре досліджено за різних температур та представлено в багатьох

Інформація про авторів:

Данилюк Олег Михайлович, аспірант, кафедра хімічної інженерії. Email: mr.danuk.91@gmail.com

Атаманюк Володимир Михайлович, д-р техн. наук, професор, завідувач кафедри хімічної інженерії. Email: atamanyuk@ukr.net; https://orcid.org/0000-0002-8707-2319

Гнатів Зоряна Ярославівна, канд. техн. наук, асистент, кафедра хімічної інженерії. Email: zorchyk@gmail.com

Гумницький Ярослав Михайлович, д-р техн. наук, професор, кафедра екології та збалансованого природокористування. Email: jgumnitsky@ukr.net; https://orcid.org/0000-0003-0464-9782

Цитування за ДСту: Данилюк О. М., Атаманюк В. М., Гнатів 3. Я., Гумницький Я. М. Дослідження масообміну під час пневматичного розчинення полідисперсної суміші бензойної кислоти. Науковий вісник НлтУ України. 2018, т. 28 , № 8. C. 101-106.

Citation APA: Danyliuk, O. M., Atamaniuk, V. M., Hnativ, Z. Ya., \& Gumnitsky, Ya. M. (2018). The investigation of mass transfer under the pneumatic dissolution of benzoic acid polydisperse mixture. Scientific Bulletin of UNFU, 28(8), 101-106.

https://doi.org/10.15421/40280821

Науковий вісник НЛТУ України, 2018, т. 28, № 8 Scientific Bulletin of UNFU, 2018, vol. 28, no 8 
довідниках. Результати розчинення бензойної кислоти в бінарній суміші розчинника (бензиловий спирт і бензальдегід) за температури 298,35-355,65 К і атмосферного тиску наведено в роботі (Wang, et al., 2015). Встановлено, що за постійного складу бінарної суміші зростання температури підвищує розчинність. Натомість, збільшення концентрації бензальдегіду знижує розчинність. Автори роботи (Qui, et al., 2015) досліджували розчинність бензойної кислоти залежно від температури, а для опису експериментальних даних використовували рівняння Вілсона. Автори стверджують, що результати їх досліджень $\epsilon$ важливими для прогнозування поведінки органічних речовин у навколишньому середовищі. Розчинність бензойної кислоти в етанолі, бензолі, етилацетаті та оцтовій кислоті та ії математичну кореляцію подано в роботі (Cheng, et al., 2012). У праці (Petrus, et al., 1998) досліджено розчинення полідисперсної твердої фази в стаціонарному шарі. Методи інтенсифікація процесу розчинення також запропоновано в роботі (Humayun, et al., 2016). Нестаціонарні аспекти розчинення за змінної рушійної сили в стаціонарному шарі дисперсного матеріалу розглянуто в роботі (Symak \& Ljuta, 2015).

Аналіз літературних джерел показує, що процес розчинення досліджено переважно для монодисперсних систем у стаціонарному шарі. Натомість, у промисловості тверда фаза є полідисперсною і потребує нових підходів до встановлення закономірностей процесів розчинення. Встановлено, що дослідженню масообміну в процесах розчинення як бензойної кислоти, так і інших солей, під час пневматичного перемішування розчину в технічній літературі приділено недостатньо уваги. Тому дослідження закономірностей масообмінних процесів під час розчинення бензойної кислоти за пневматичного перемішування, визначення ефективних коефіцієнтів молекулярної дифузії та масовіддачі є актуальними завданнями.

Мета роботи полягала в дослідженні особливостей масообміну процесу розчинення полідисперсної суміші бензойної кислоти під час пневматичного перемішування розчину.

Об'єктом дослідження був процес розчинення бензойної кислоти у воді та особливості масообміну між твердою фазою та рідиною під час пневматичного перемішування розчину.

Експериментальні дослідження. Аналіз руху бульбашок стисненого повітря у рідкому середовищі проводили на лабораторній установці, схему і принцип роботи якої представлено в роботі (Danyliuk, et al., 2017).

Важливим у процесі масообміну в середовищі "тверда фаза-рідина" є визначення коефіцієнтів масовіддачі, залежності коефіцієнта масовіддачі від концентрації розчину, а також дослідження зміни поверхні масообміну внаслідок зміни діаметра частинок полідисперсної твердої фази зі зміною концентрації.

Кількість частинок $N_{\text {ч }}$ у наважці полідисперсної суміші бензойної кислоти, що подаються на розчинення, визначали за такою залежністю:

$$
N_{u}=\frac{6}{\rho \cdot \pi} \cdot \sum_{j=1}^{5} \frac{m_{j}}{\bar{d}_{u j}^{3}},
$$

де: 5 - кількість фракцій полідисперсної суміші бензойної кислоти; $m_{j}$ - маса наважки бензойної кислоти $j$-тої фракції, кг; $\rho$ - густина бензойної кислоти, кг/м ${ }^{3}$; $\bar{d}_{i j}$ - усереднений початковий діаметр $j$-тої фракції, м.
Основні характеристики полідисперсної суміші бензойної кислоти, розділеної на п'ять фракцій, наведено у табл. 1. Масу твердої бензойної кислоти, яка перейшла в розчин за певний проміжок часу, розраховували за такою залежністю:

$$
m_{p i}=V \cdot\left(C_{i}-C_{i-1}\right), i=\overline{1, m},
$$

де: $m$ - кількість точок експерименту; $C_{i}-C_{i-1}-$ зміна концентрації бензойної кислоти в розчині за певний

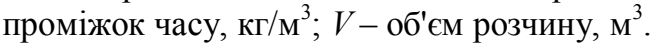

Маса бензойної кислоти, яка залишилася нерозчиненою у розчині розраховували за такою залежністю:

$$
m_{\tau i}=m_{i-1}-m_{p i}, i=\overline{1, m} \text {. }
$$

Табл. 1. Основні характеристики полідисперсної суміші бензойної кислоти

\begin{tabular}{|c|c|c|c|}
\hline Фракція $x \cdot 10^{3}, \mathrm{м}$ & $m$, кг & $\bar{d}_{u} \cdot 10^{6}, \mathrm{M}$ & $N_{u j}$ \\
\hline $0,16-0,315$ & $7,63 \mathrm{E}-05$ & 176 & 21070 \\
\hline $0,315-0,63$ & $6,14 \mathrm{E}-04$ & 338 & 23914 \\
\hline $0,63-1,25$ & $2,46 \mathrm{E}-03$ & 666 & 12534 \\
\hline $1,25-2,5$ & $1,15 \mathrm{E}-03$ & 1116 & 1245 \\
\hline $2,5-5,0$ & $1,99 \mathrm{E}-04$ & 1753 & 55 \\
\hline$\sum$ & 0,00450 & & 58819 \\
\hline
\end{tabular}

3 огляду на те, що експериментально визначити зміну розмірів частинок кожної фракції неможливо, робили припущення, що діаметри всіх частинок зменшуються на однакову величину $\Delta$. Це припущення обгрунтовували тим, що частинки всіх фракцій рівномірно омиваються рідиною і їх розчинність також буде рівномірною, тобто розміри всіх частинок будуть зменшуватися на одну і ту ж величину $\Delta$.

Кількість нерозчиненої бензойної кислоти після кожного експерименту представляли в такому вигляді:

$$
m_{T i}=\frac{\pi \cdot \rho}{6} \cdot \sum_{j=1}^{n} N_{i, j} \cdot\left(d_{i, j}-\Delta_{i}\right)^{3}, i=\overline{1, m} .
$$

Розв'язавши кубічне рівняння відносно невідомої величини $\Delta_{i}$, за допомогою функції Find програмного комплексу MathCad 15, отримали числові значення $\Delta_{i}$, для кожного експерименту.

Теоретично розраховані значення зміни в часі діаметрів частинок бензойної кислоти для кожної із фракцій наведено на рис. 1.

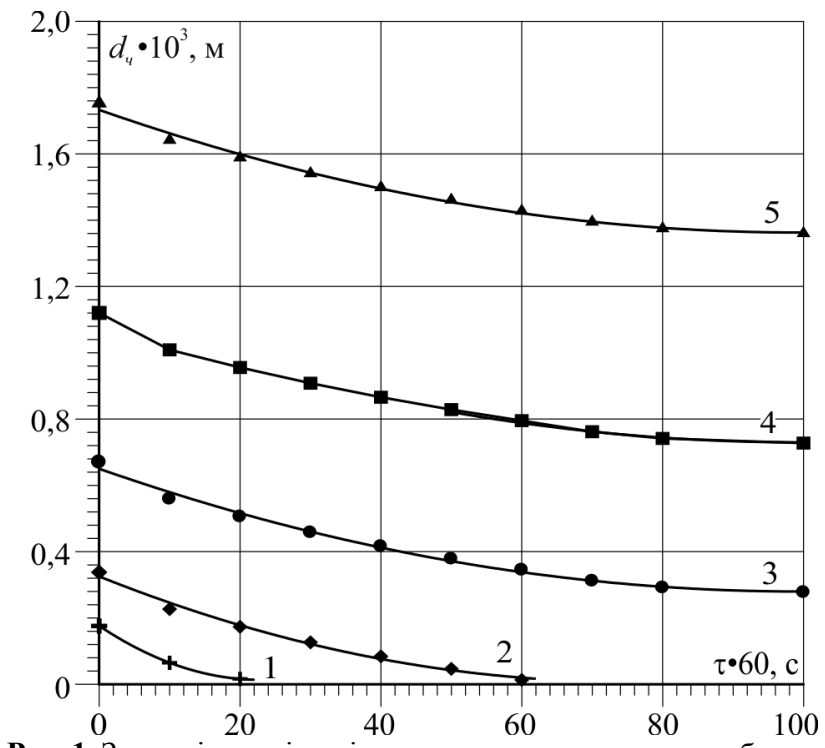

Рис. 1. Залежність зміни діаметра дисперсних частинок бензойної кислоти у часі для фракцій: $1-(0,16 \div 0,315) \cdot 10^{-3} \mathrm{M} ; 2-$ $(0,315 \div 0,63) \cdot 10^{-3} \mathrm{M} ; 3-(0,63 \div 1,25) \cdot 10^{-3} \mathrm{M} ; 4-(1,25 \div 2,5) \cdot 10^{-3} \mathrm{M}$; $5-(2,5 \div 5,0) \cdot 10^{-3} \mathrm{M}$ 
За результатами проведених розрахунків бачимо, що через 20 хв повністю розчиняється найменша фракція $(0,16 \div 0,315) \cdot 10^{-3} \mathrm{M}, \quad$ a через $60 \mathrm{xв}-$ фракція $(0,63 \div 1,25) \cdot 10^{-3} \mathrm{M}$.

Поряд із розчиненням окремих фракцій суміші бензойної кислоти необхідно встановити особливості масообміну для всієї полідисперсної суміші.

Початкову поверхню частинок всіх фракцій визначали із залежності

$$
F_{0}=\pi \cdot \sum_{j=1}^{5} N_{u_{0, j}} \cdot d_{u_{0, j}}^{2}
$$

Поверхня масообміну під час розчинення зменшується в часі, а концентрація розчину при цьому зростає. Зміну сумарної поверхні частинок під час експерименту визначали зі залежності

$$
F_{i}=\pi \cdot \sum_{j=1}^{n} N_{u_{\mathrm{i}, j}} \cdot d_{u_{\mathrm{i}, j}}^{2}, i=\overline{1, m} .
$$

Коефіцієнт масовіддачі від твердих частинок бензойної кислоти в розчин знаходили зі залежності

$$
\beta_{i}=\frac{m_{P_{i}}}{F_{i} \cdot\left(C_{s}-\frac{C_{i}+C_{i-1}}{2}\right) \cdot \tau_{i}}, i=\overline{1, m},
$$

де: $C_{s}-$ концентрація насичення для бензойної кислоти у воді за температури експерименту, кг $/ \mathrm{m}^{3} ; \tau_{i}-$ час між відборами проб, с.

На рис. 2 зображено зміну коефіцієнта масовіддачі полідисперсної бензойної кислоти зі зміною концентрації розчину за сталої витрати повітря.

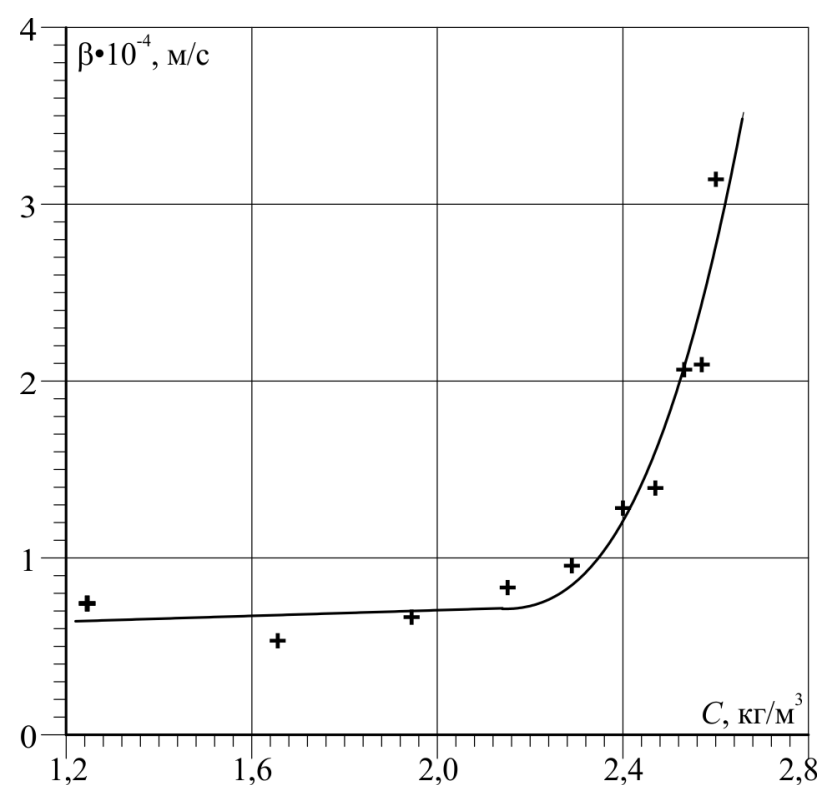

Рис. 2. Залежність зміни коефіцієнта масовіддачі полідисперсної бензойної кислоти зі зміною концентрації розчину за умов сталої витрати повітря $\left(\mathrm{Vc}=1,33 \cdot 10^{-3}, \mathrm{~m}^{3} / \mathrm{c}\right)$

На рис. 3 показано залежність коефіцієнта масовіддачі зі зміною концентрації розчину в часі та за змінної витрати стиснутого повітря.

Результати розрахунків дисипації енергії, яка вводиться у апарат для розчинення бензойної кислоти під час пневматичного перемішування в умовах квазістатичного руху бульбашок повітря, отримано згідно з методикою (Ostrovskij, 2000), яку наведено у табл. 3. на підстаі обчислених результатів побудовано графік залежності коефіцієнта масовіддачі від зміни дисипації енергії в апараті за змінної витрати повітря (рис. 4).

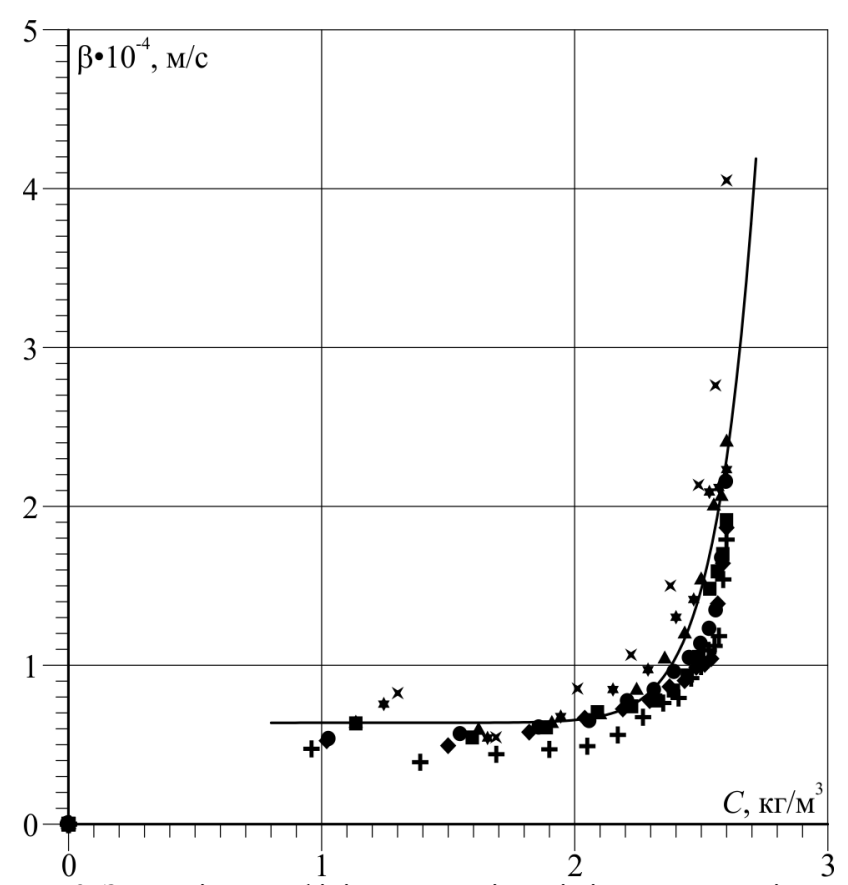

Рис. 3. Залежність коефіцієнта масовіддачі від концентрації розчину зі зміною витрати стиснутого повітря під час розчинення полідисперсної бензойної кислоти у воді: $+-0,22 \cdot 10^{-3}$ $\mathrm{m}^{3} / \mathrm{c} ;-0,44 \cdot 10^{-3}, \mathrm{~m}^{3} / \mathrm{c} ;-0,67 \cdot 10^{-3}, \mathrm{~m}^{3} / \mathrm{c} ; \bullet-0,89 \cdot 10^{-3}, \mathrm{~m}^{3} / \mathrm{c} ;$

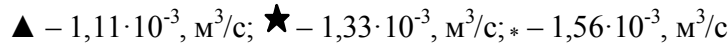

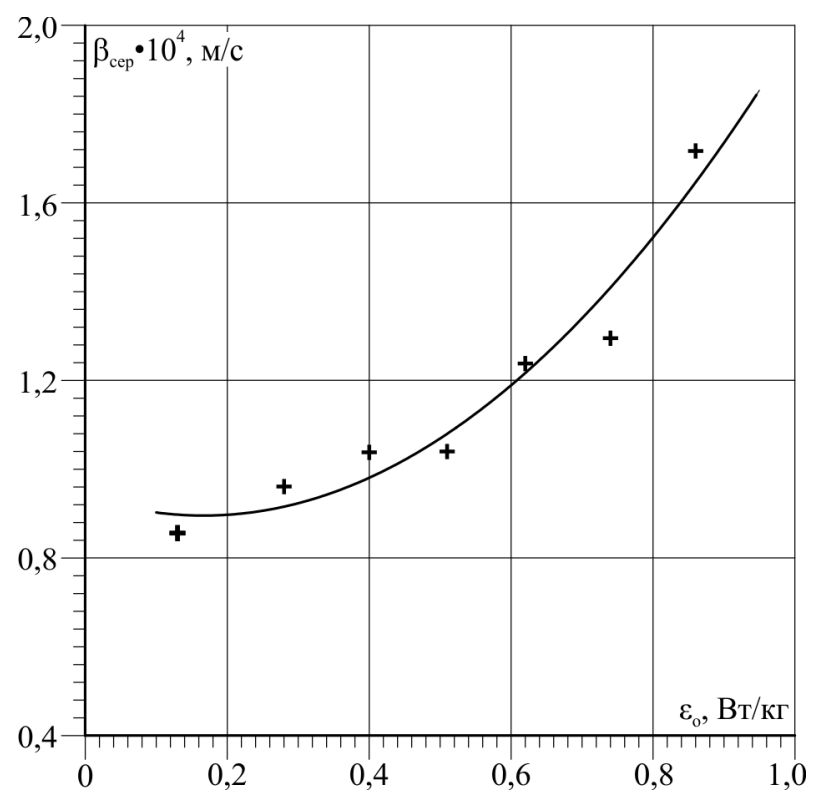

Рис. 4. Залежність зміни коефіцієнта масовіддачі зі зміною дисипації енергії в апараті під час розчинення бензойної кислоти за різних витрат стиснутого повітря

3 рис. 4 видно, що коефіцієнт масовіддачі $\beta_{\text {сер зі }}$ зростанням витрати повітря і дисипації енергії в апараті зростає, що пояснюємо зростанням швидкості омивання твердих частинок розчином та зменшенням товщини пограничного шару навколо твердої частинки.

Враховуючи те, що концентрація бензойної кислоти під час проведення дослідів була незначною $\left(C_{s}=2,63\right.$ $\left.\kappa г / \mathrm{M}^{3}\right)$, розрахунок числа Шмідта визначали як для чистої дистильованої води. Вихідні дані наведено у табл. 2.

Коефіцієнт молекулярної дифузії $D^{t}$ за температури експерименту визначали із залежності (Lykov, 1972):

$$
D^{t}=D^{20} \cdot[1+b \cdot(t-20)],
$$

де $b$ - коефіцієнт, який визначають із такої залежності (Lykov, 1972): 


$$
b=0,2 \cdot \sqrt{\mu} \cdot \sqrt[3]{\rho},
$$

де: $\mu$ - коефіцієнт динамічної в'язкості розчину за температури експерименту, Па·с; $\rho$ - густина розчину за температури експерименту, кг/м².

Число Шмідта визначали із залежності

$$
S c=\frac{v}{D^{16}},
$$

де $v$ - кінематична в'язкість розчину, $\mathrm{m}^{2} / \mathrm{c}$.

Табл. 2. Фізичні характеристики розчину

\begin{tabular}{|c|c|c|c|c|c|}
\hline $\begin{array}{c}v \cdot 10^{-5} \\
\mathrm{M}^{2} / \mathrm{c}\end{array}$ & $\mu^{16^{16} \mathrm{C}}$ Па $\cdot \mathrm{c}$ & $\rho$, кг $/ \mathrm{M}^{3}$ & $b$ & $D^{16}, \mathrm{M}^{2} / \mathrm{c}$ & $S c^{16^{\mathrm{C}}}$ \\
\hline 0,1 & 0,001 & 1000 & 0,063 & $8,59 \mathrm{E}-10$ & 1164 \\
\hline
\end{tabular}

Вихідні дані для розрахунку числа Шервуда наведено у табл. 3 .

Значення числа Рейнольдса визначали із залежності

$$
\operatorname{Re}^{*}=\frac{\sqrt[3]{\omega_{0} \cdot g \cdot L} \cdot d_{u_{i}}}{v}
$$

де: $\omega_{0}-$ фіктивна швидкість газу 3 отвору барботера, м/с; $L=0,155$ - лінійний розмір (діаметр) апарату, м; $d_{4 i}-$ середній діаметр частинок впродовж досліду за відповідної витрати стиснутого повітря, м.

Значення числа Шервуда визначали із залежності

$$
S h=\frac{\beta \cdot d_{u_{i}}}{D^{16}} .
$$

Графічну залежність коефіцієнта масовіддачі від об'ємної витрати стиснутого повітря наведено на рис. 5.

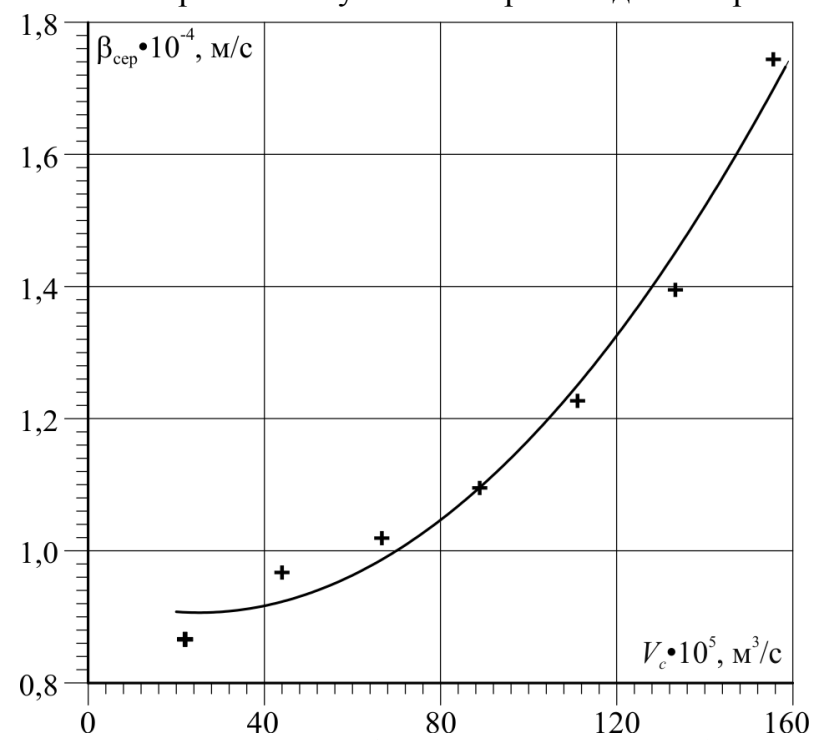

Рис. 5. Залежність зміни коефіцієнта масовіддачі зі зміною дисипації енергії в апараті під час розчинення
Коефіцієнт масовіддачі від поверхні твердої частинки в розчин залежить від гідродинамічного режиму, за якого здійснюється процес. Із рис. 5 видно, що коефі-

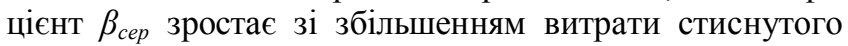
повітря. Розраховані значення коефіцієнта масовіддачі $\beta_{c e p}$ для різних витрат стиснутого повітря наведено у табл. 3.

Критеріальне рівняння для визначення чисел Шервуда представляли у такому вигляді:

$$
S h^{*}=A \cdot \mathrm{Re}^{* m} \cdot \sqrt[3]{S c}
$$

де $A, m-$ невідомі коефіцієнти, які визначають на підстаі експериментальних даних.

Враховуючи те, що фізичні параметри розчину змінюються у вузькому діапазоні, згідно з рекомендаціями (Gelperin, 1981), приймаємо:

тобто $m=0,33$.

$$
S h \approx S c^{0,33}
$$

Для визначення невідомих коефіцієнтів А і m експериментальні дані представляли у вигляді графічної залежності $S h / \sqrt[3]{S c}=f(\operatorname{Re})$ у логарифмічних координатах (рис. 6).

\begin{tabular}{|c|c|c|c|c|c|c|c|c|}
\hline$V c 10^{5}, \mathrm{~m}^{3} / \mathrm{c}$ & $\varepsilon_{0}, \mathrm{BT} / \mathrm{K} \Gamma$ & $d_{c} \cdot 10^{-3}, \mathrm{M}$ & $\beta_{c e p} \cdot 10^{-4}, \mathrm{M} / \mathrm{c}$ & $R e^{*}$ & $S h$ & $S c^{1 / 3}$ & $S h / S c^{1 / 3}$ & $S h^{*}$ \\
\hline 22 & 0,13 & 0,520 & 0,866 & 162,31 & 52,42 & \multirow{7}{*}{10,52} & 4,98 & 48,76 \\
\hline 44 & 0,28 & 0,517 & 0,967 & 184,73 & 58,20 & & 5,53 & 57,31 \\
\hline 67 & 0,40 & 0,520 & 1,019 & 204,50 & 61,68 & & 5,86 & 65,08 \\
\hline 89 & 0,51 & 0,518 & 1,095 & 219,44 & 66,03 & & 6,28 & 71,08 \\
\hline 111 & 0,62 & 0,528 & 1,227 & 237,69 & 75,42 & & 7,17 & 78,54 \\
\hline 133 & 0,74 & 0,531 & 1,395 & 251,65 & 86,23 & & 8,20 & 84,35 \\
\hline 156 & 0,86 & 0,542 & 1,744 & 268,55 & 110,04 & & 10,46 & 100,40 \\
\hline
\end{tabular}

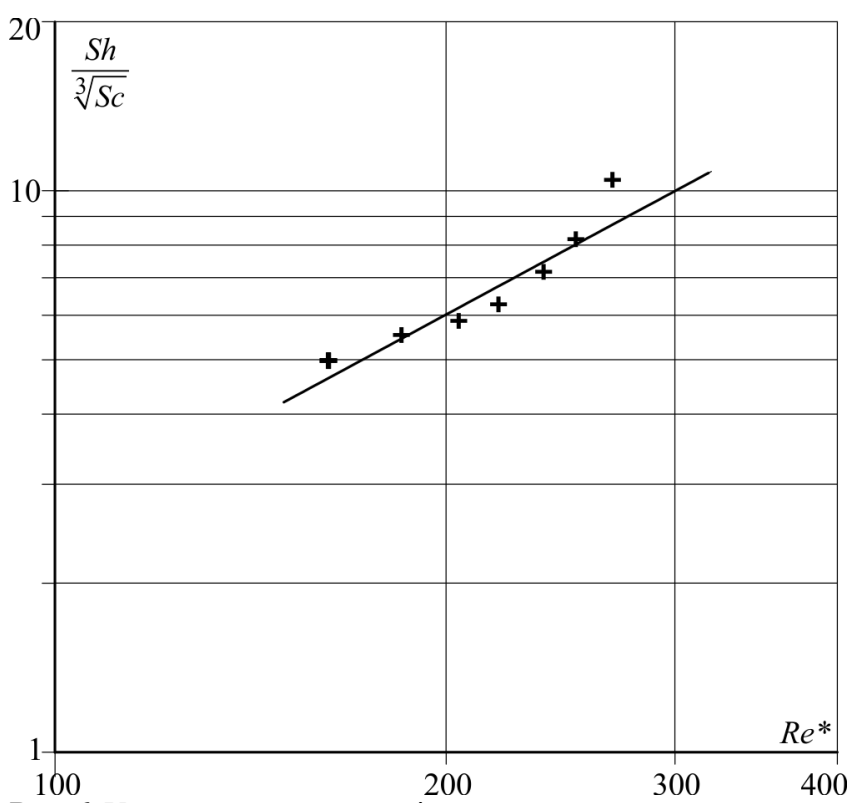

Рис. 6. Узагальнення результатів експериментального визначення коефіцієнта масовіддачі бензойної кислоти під час пневматичного перемішування

Табл. 3. Результати експериментальних досліджень та визначені числа Шервуда для різних витрат стиснутого повітря

$S h, S h^{*}$ - експериментальне та теоретично розраховане на підстаі залежності (13) значення чисел Шервуда, відповідно.

Коефіцієнт $m$ є тангенсом кута нахилу прямої до осі абсцис. Апроксимувавши результати експериментальних досліджень степеневою функцією, отримали розрахункову залежність для визначення числа Шервуда у вигляді:

$$
S h^{*}=8 \cdot 10^{-3} \cdot \mathrm{Re}^{1,25} \cdot \sqrt[3]{S c} .
$$

Отримана розрахункова залежність (14) дає змогу 3 достатньою для практичних розрахунків точністю визначити значення числа Шервуда i, відповідно, коефіцієнта масовіддачі в межах зміни числа Рейнольдса $100 \leq \operatorname{Re} \leq 300$. 
На рис. 7 зображено порівняння визначених на підстаі розрахункової залежності (13) чисел Шервуда 3 експериментальними значеннями.

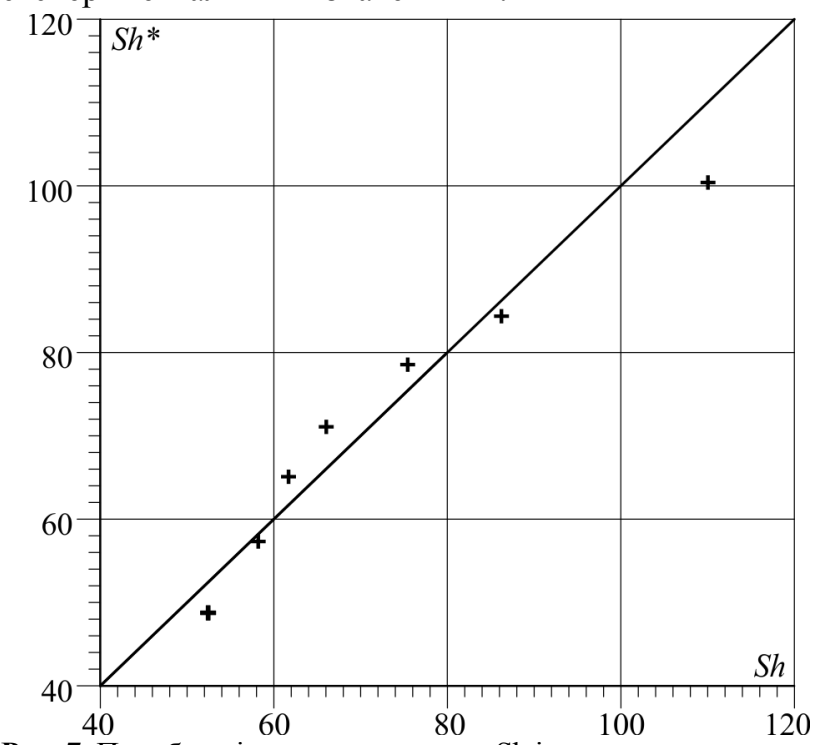

Рис. 7. Похибка між розрахунковими Sh i експериментальними $\mathrm{Sh}^{*}$ значеннями чисел Шервуда

Похибку між ними знаходили за залежністю (16) i вона не перевищувала $10 \%$ :

$$
\delta=\frac{S h-S h^{*}}{S h^{*}} \cdot 100 \% .
$$

Висновки. У роботі наведено результати експериментальних досліджень розчинення бензойної кислоти під час пневматичного перемішування розчину. Отримано залежності зміни діаметрів полідисперсних частинок бензойної кислоти від зміни концентрації розчину за сталої та змінної витрат стисненого повітря для полідисперсної суміші та окремо для кожної із фракцій. Наведено розраховані та експериментальні результати, згідно з якими площа поверхні масообміну полідисперсної суміші бензойної кислоти зменшується в часі зі зростанням концентрації розчину. на підстаі експериментальних досліджень та обчислених даних встановлено значення коефіцієнта масовіддачі під час розчинення полідисперсної суміші бензойної кислоти за різних витрат повітря. Отримано залежність коефіцієнта масовіддачі від зміни дисипації енергії в об'ємі апарату під час розчинення бензойної кислоти. Зроблено узагальнення результатів експериментального визначення коефіцієнта масовіддачі бензойної кислоти під час пневматичного перемішування. Також узагальнено залежність коефіцієнта масовіддачі від концентрації розчину бензойної кислоти зі зміною витрати стиснутого повітря у межах 0,8-5,6 м 3 /год. Отримано рівняння розрахункового значення критерію Шервуда у вигляді: $S h^{*}=8 \cdot 10^{-3} \cdot \mathrm{Re}^{1,25} \cdot \sqrt[3]{S c}$. Визначено коефіцієнт молекулярної дифузії, а також порівняно експериментальні дані $з$ теоретично розрахованими. Порівняно теоретично розраховані та експериментально визначені значення критеріїв Шервуда, оцінено похибку між розрахованими та експериментальними значеннями.

\section{Перелік використаної літератури}

Cheng, W., Feng, S., Cui, X., et al. (2012). Solubility of Benzoic Acid in Ethanol, Benzene, Acetic Acid and Ethyl Acetate from 291.69 to 356.27 K. Adv. Mater. Res., 518/523, 3975-3979.

Danyliuk, O. M., Atamaniuk, V. M., Gumnyckyj, Ja. M., \& Bachyk, M. D. (2017). Doslidzhennja zakonomirnostej procesu rozchynennja polidyspersnyh chastynok benzojnoi kysloty pid chas pnevmatychnogo peremishuvannja. Integrovani tehnologii ta energozberezhennja, 4, 36-40. [In Ukrainian].

Eryh, L., \& Martyn, Ja. (1998). Konservanti v pyshhevoj promyshlennosty, 3 (pp. 123-128). St. Petersburg: GYORD, 256 p. [In Russian].

Garner, F. H., \& Hoffman, J. M. (1960). The transition from free to forced convection in mass transfer from solid spheres. AIChE Jornal, 6(4), 579-584. https://doi.org/10.1002/aic.690060415

Gelperin, N. I. (1981). Osnovnye processy i apparaty himicheskoj tehnologii. In 2nd books. Moscow: Himija, 812 p. [In Russian].

Harlashin, P. S., Beket, V. Ja., \& Bendich, A. V. (2012). Kineticheskie osobennosti rastvorenija tverdyh tel $\mathrm{v}$ zhidkom rasplave. Visnik Priazovskogo derzhavnogo tehnichnogo universitetu, 25, 13-19. [In Russian].

Humayun, H., Shaarani, M., et al. (2016). The Effect of Co-solvent on the Solubility of a Sparingly Soluble Crystal of Benzoic Acid. Procedia Eng., $\quad 148, \quad 1320 \quad$ p. https://doi.org/10.1016/j.proeng.2016.06.548

Lykov, A. V. (1972). Teplo-massoobmen. Moscow: Jenergija, 660 p. [In Russian].

Melihov, I. V., Dolgonosov, B. M., Elenin, G. G., \& Sosnin, N. V. (1989). Rastvorenie polidispersnoj tverdoj fazy v plotnom sloe. Teoreticheskie osnovy himmicheskih Tehnologii, 23(1), 101-104. [In Russian].

Osokina, N. M., \& Gerasymchuk, O. P. (2008). Zastosuvannja rechovyn antymikrobnoi dii dlja pidvyshhennja terminu zberigannja jagid chornoi smorodyny. Tovary i rynky, 1, 162-167. [In Ukrainian].

Ostrovskij, G. (2000). Prikladnaja mehanika neodnorodnih sred, (pp. 338-339). St. Petersburg: Science, 360 p. [In Russian].

Petrus, R., Akselrud, G., Gumnitsky, Ya., \& Piantkowski, W. (1998). Wymiana masy w ukladzie cialo stale. Rzeszow: Wyd. Politechniki Rzeszowskiej, $365 \mathrm{p}$.

Qui, Y., Li, X., Li, G., et al. (2015). The role of the solid-solution interface in the dissolution of benzoic acid. Chemical Engineering Science, 123, 376 p. https://doi.org/10.1016/j.ces.2014.11.031

Symak, D. M., \& Ljuta, O. V. (2015). Nestacionarnyj proces rozchynennja sharu zernystogo materialu. (Ser. Himija, tehnologija rechovyn ta ih zastosuvannja). Visnyk Nacionalnogo universytetu "L'vivska politehnika", 812, 308-312. [In Ukrainian].

Symak, D. M., Atamaniuk, V., \& Gumnitsky, Ya. (2015). Analysis of dissolution kinetics dased on the lokal isotropic turbulence theory. Chemistry \& Chemical Technology, 9(4), 493-497.

Thati, Jyothi, Nordström, Fredrik, L., \& Rasmuson, Åke C. (2010). Solubility of Benzoic Acid in Pure Solvents and Binary Mixtures. $J$. Chem. Eng., 55(11), 5124-5127. https://doi.org/10.1021/je100675r

Wang, H., Wang, Q., Xiong, Z., et al. (2015). Solubilities of benzoic acid in binary (benzyl alcohol + benzaldehyde) solvent mixtures. $J$. Chem. Thermodyn, 83, 61-69. https://doi.org/10.1016/j.jct.2014.12.003

О. М. Данилюк, В. М. Атаманюк, З. Я. Гнатив, Я.М. Гумницкий

Национальный университет "Львовская политехника", г. Львов, Украина

\section{ИССЛЕДОВАНИЕ МАССООБМЕНА ПРИ ПНЕВМАТИЧЕСКОМ РАСТВОРЕНИИ ПОЛИДИСПЕРСНОЙ СМЕСИ БЕНЗОЙНОЙ КИСЛОТЫ}

Приведены результаты экспериментальных исследований растворения бензойной кислоты во время пневматического перемешивания. Проведен анализ литературных источников и показана актуальность исследования закономерностей массо- 
обменных процессов при растворении полидисперсных смесей. Обосновано предположение об изменении диаметров твердых частиц во время растворения. Получены зависимости изменения диаметра полидисперсных частиц бензойной кислоты от изменения концентрации раствора при постоянной и переменной расхода сжатого воздуха для полидисперсной смеси бензойной кислоты и отдельно для каждой из фракций. Приведены вычисленные и экспериментальные результаты, согласно которым площадь поверхности массообмена полидисперсной смеси бензойной кислоты уменьшается во времени с ростом концентрации раствора. Получена зависимость коэффициента массоотдачи от изменения диссипации энергии в объеме аппарата во время растворения бензойной кислоты. Проанализировано влияние изменения расхода сжатого воздуха на коэффициент массоотдачи. Сделано обобщение результатов экспериментального определения коэффициента массоотдачи бензойной кислоты во время пневматического перемешивания. Определен коэффициент молекулярной диффузии при данной температуре, а также проведено сравнение экспериментальных данных с теоретически рассчитанными. Получена расчетная зависимость для расчета значений чисел Шервуда, а также проведено их сравнение с данными экспериментальных исследований. Оценена погрешность проведенных расчетов.

Ключевые слова: бензойная кислота; полидисперсная смесь; растворение; коэффициент массоотдачи; пневматическое перемешивание; диффузия.

O. M. Danyliuk, V. M. Atamaniuk, Z. Ya. Hnativ, Ya. M. Gumnitsky Lviv Polytechnic National University, Lviv, Ukraine

\section{THE INVESTIGATION OF MASS TRANSFER UNDER THE PNEUMATIC DISSOLUTION} OF BENZOIC ACID POLYDISPERSE MIXTURE

In this paper we present the results of experimental studies of the dissolution of benzoic acid under the pneumatic mixing. The analysis of literary sources is carried out and the relevance of the study of the laws of mass-exchange processes during the dissolution of polydisperse mixtures is shown. The assumption concerning the change in the diameter of solid particles during dissolution is substantiated. The dependences of the change in the diameter of the polydispersed particles of benzoic acid on the change in the concentration of the solution under constant and variable compressed air consumption for a polydispersed mixture of benzoic acid and separately for each of the fractions were obtained. The authors also present the calculated and experimental results, according to which the surface area of the mass transfer of the polydispersed mixture of benzoic acid decreases in time with increasing concentration of the solution. The coefficient of mass transfer from the surface of a solid particle in to the solution depends on the hydrodynamic regime of the process. The dependence of the coefficient of mass transfer on the energy dissipation in the volume of the apparatus during the dissolution of benzoic acid is obtained. The mass transfer coefficient increases with increasing air flow and energy dissipation in the apparatus, which is explained by the growth of the rate of washing of solid particles by the solution and the decrease of the thickness of the boundary layer around the solid. We have also analyzed the influence of change in the flow of compressed air on the coefficient of mass transfer. A generalization of the results of the experimental determination of the mass ratio of benzoic acid during the pneumatic mixing is made. Furthermore, the dependence of the mass transfer coefficient on the concentration of the solution of benzoic acid with the change in the flow of compressed air in the range of $0.8-5.6 \mathrm{~m}^{3} / \mathrm{h}$ was investigated. The molecular diffusion coefficient at the given temperature is determined, as well as comparatively experimental data with the theoretically calculated ones. The calculated dependence for calculating the values of Sherwood numbers is obtained, and it was also compared with the data of experimental studies. Finally, the estimation error of the performed calculations was experimentally conducted in the work.

Keywords: benzoic acid; polydisperse mixture; dissolution; mass transfer coefficient; pneumatic mixing; diffusion. 